\title{
Rituximab: Apakah Efektif dalam Tata Laksana Sindrom Nefrotik?
}

\author{
Sudung O. Pardede, * Dimas K. Bonardo** \\ *Departemen Ilmu Kesehatan Anak Fakultas Kedokteran Universitas Indonesia-RS Dr. Cipto Mangunkusumo, \\ Jakarta \\ **Rumah Sakit PGI Cikini, Jakarta
}

\begin{abstract}
Sebagian besar pasien sindrom nefrotik memberikan respons yang baik dengan steroid, tetapi terdapat pasien yang tidak responsif dengan steroid dan sulit mengalami remisi, disebut sindrom nefrotik refrakter. Berbagai regimen obat telah diberikan untuk menghindari atau mengurangi efek samping steroid, seperti siklofosfamid, klorambusil, siklosporin, vinkristin, mikofenolat mofetil, dan takrolimus dengan hasil yang bervariasi dan berbagai efek samping. Rituximab adalah antibodi monoklonal anti-CD20 yang menginduksi aktivitas imunologis yang dimediasi oleh komplemen dan mencetuskan aktivitas selular tergantung antibodi (antibody-dependent). Rituximab telah diberikan untuk mengobati sindrom nefrotik refrakter, dan pada sindrom nefrotik relaps sering, terjadi remisi dan tidak timbul relaps. Penelitian multisenter untuk sindrom nefrotik dependen steroid dan resisten steroid, memperlihatkan terjadi remisi pada sebagian besar pasien. Pemberian rituximab pada sindrom nefrotik dengan gambaran patologi anatomi kelainan minimal, nefropati membranosa, dan glomerulosklerosis fokal segmental menyebabkan remisi pada sebagian besar pasien. Keberhasilan rituximab dalam tata laksana sindrom nefrotik idiopatik merupakan bukti terdapatnya peran limfosit B dalam patogenesis sindrom nefrotik. Dosis yang sering digunakan $375 \mathrm{mg} / \mathrm{m}^{2} \mathrm{LPB}$ secara intravena diberikan 4 dosis dengan interval satu minggu atau dosis $750 \mathrm{mg} / \mathrm{m}^{2} \mathrm{LPB}$ diberikan dua dosis selang waktu dua minggu. Rituximab dapat mengurangi aktivitas penyakit dan memperbaiki sensitivitas terhadap obat imunsupresan. Efek samping yang sering terjadi berupa reaksi akut seperti demam, nyeri abdomen, diare, muntah, ruam kulit, bronkospasme, takikadia, dan hipertensi. Rituximab memberikan hasil yang baik dalam tata laksana sindrom nefrotik refrakter, namun diperlukan uji klinik dengan jumlah sampel yang cukup untuk menilai efikasi dan keamanan obat. Sari Pediatri 2011;13(4):285-92.
\end{abstract}

Kata kunci: rituximab, sindrom nefrotik dependen steroid, sindrom nefrotik resisten steroid

\footnotetext{
Alamat korespondensi:

Dr. Sudung O. Pardede, Sp.A(K). Divisi Nefrologi. Departemen Ilmu Kesehatan Anak Fakultas Kedokteran Universitas Indonesia Jl. Salemba no. 6, Jakarta 10430. Telepon: 021-3915179. Fax.021-390 7743.
}

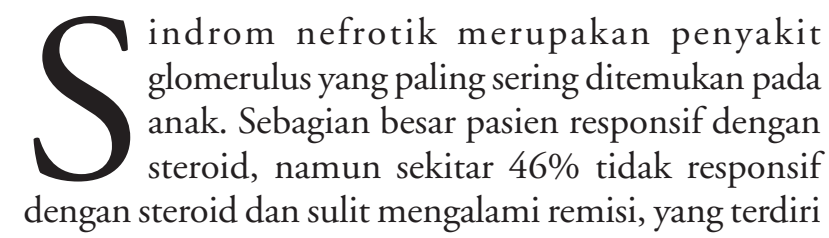


dari sindrom nefrotik resisten steroid (SNRS) 50\%-60\% dan 40\%-50\% sindrom nefrotik relaps frekuen (SNRF) atau dependen steroid (SNDS). Sindrom nefrotik jenis tidak responsif steroid disebut dengan sindrom nefrotik refrakter. Berbagai regimen pengobatan non steroid telah diberikan untuk menghindari atau mengurangi efek samping steroid, seperti obat alkilating (siklofosfamid, klorambusil), alkaloid vinka (vinkristin), imunosupresan antiproliferatif (mikofenolat mofetil, inhibitor kalsineurin (siklosporin A, takrolimus), obat imunomodulator (levamisol), angiotensin converting enzyme inhibitor (ACE inhibitor), dan plasma exchange. Meskipun banyak peneliti melaporkan keberhasilan dengan obat tersebut, banyak juga laporan tentang ketidakberhasilan dengan obatobatan tersebut. Relaps masih sering terjadi disertai efek samping baik oleh steroid maupun imunosupresan tersebut, misalnya obat siklosporin dapat menyebabkan efek samping nefrotoksik kronik, dan siklofosfamid dapat menimbulkan toksisitas gonad (azoospermia). Steroid menyebabkan obesitas, katarak, gagal tumbuh, dan osteonekrosis. Akibat efek samping tersebut, pada pemakaian obat imunosupresan perlu diperhitungkan dosis kumulatif. ${ }^{1}$

Akhir-akhir ini, telah banyak dilaporkan pemberian rituximab, baik dalam pertemuan ilmiah internasional maupun dalam jurnal kedokteran. Rituximab adalah antibodi monoklonal anti-CD20 yang telah digunakan untuk terapi berbagai penyakit autoimun. ${ }^{1,2,3,4}$ Dari penelusuran literatur tentang rituximab dan sindrom nefrotik, sebagian besar literatur merupakan laporan kasus, beberapa merupakan seri kasus, dan sedikit yang merupakan penelitian prospektif dengan jumlah kasus yang tidak banyak. Makalah ini bertujuan merangkum berbagai literatur tentang pemberian rituximab dalam tata laksana sindrom nefrotik refrakter seperti sindrom nefrotik relaps frekuen/dependen steroid dan sindrom nefrotik resisten steroid.

\section{Penggunaan rituximab}

Rituximab sudah digunakan pada beberapa penyakit autoimun pada pasien dewasa dan anak, baik sebagai monoterapi maupun sebagai tambahan terapi konvensional. Beberapa penyakit autoimun tersebut antara lain, limfoma sel B, anemia hemolitik autoimun, purpura trombositopeni imun, neuropati IgM-mediated, vaskulitis positif-anti-neutrophil cytoplasmic antibody (ANCA), artritis reumatoid, lupus eritematosus sistemik, penyakit limfoproliferatif pasca transplantasi, rejeksi akut pasca transplantasi, dan nefropati membranosa dengan hasil yang baik. ${ }^{4}$ Rituximab telah digunakan terhadap lebih dari 300.000 pasien limfoma sel B dengan dosis $375 \mathrm{mg} /$ $\mathrm{m}^{2}$ luas permukaan badan (LPB) yang diberikan empat dosis setiap minggu. Keberhasilan rituximab dalam terapi penyakit autoimun, menimbulkan dugaan kuat terhadap peran sel-B dalam patogenesis penyakit autoimun. ${ }^{1,2}$

Edelbauer $\mathrm{dkk}^{5}$ melaporkan anak dengan lupus eritematosus sistemik yang refrakter terhadap imunosupresan konvensional, diobati dengan rituximab dan terdapat perbaikan klinis ekstrarenal, meskipun tidak terjadi remisi total, namun hematuria dan proteinuria tidak mengalami perubahan. Marks dan Tullus ${ }^{6}$ mengobati 19 pasien lupus eritematosus sistemik dengan rituximab $750 \mathrm{mg} / \mathrm{m}^{2} \mathrm{LPB}$ diberikan dua kali selang waktu dua minggu, dan setelah dipantau selama rerata 23 bulan, didapatkan 13 (54\%) pasien dalam keadaan baik dan tidak memerlukan pemberian imunosupresan lain. Nwobi $\mathrm{dkk}^{7}$ melaporkan 15 pasien lupus eritematosus sistemik yang diterapi dengan rituximab. Pada 93\% didapatkan perbaikan klinis, fungsi ginjal, double-stranded DNA (dsDNA) antibodies, dan proteinuria. Deplesi sel B terjadi dalam dua minggu setelah pemberian rituximab. Pada pasien lupus eritematosus sistemik yang diterapi dengan rituximab, terdapat peningkatan bermakna sel $\mathrm{T}$ regulatori (TREG) dan peningkatan sel $\mathrm{T}$ apoptotik. Angka kejadian remisi secara umum pada lupus eritematosus sebesar sekitar $89 \% .{ }^{8}$ Rituximab juga dilaporkan berhasil dalam pengobatan berbagai penyakit ginjal. ${ }^{3}$ Beberapa peneliti melaporkan keberhasilan rituximab dalam tata laksana sindrom nefrotik refrakter. Pemberian rituximab dalam tata laksana sindrom nefrotik didasarkan pada patogenesis, yaitu dapat menyebabkan deplesi sel B. ${ }^{1}$

\section{Sindrom nefrotik refrakter}

Sindrom nefrotik adalah keadaan klinis yang ditandai dengan proteinuria masif (proteinuria $\geq 2+$ dengan dipstik, atau protein urin $>40 \mathrm{mg} / \mathrm{m}^{2} / \mathrm{jam}$, atau $>50$ $\mathrm{mg} / \mathrm{kgbb} / \mathrm{hari}$, atau rasio protein:kreatinin $>2 \mathrm{mg} / \mathrm{mg}$ ); hipoalbuminemia (albumin $<2,5 \mathrm{~g} / \mathrm{dL}$ ), edema, dan hiperkolesterolemia. 
Lebih dari tigapuluh tahun diyakini bahwa sindrom nefrotik terjadi karena disfungsi sel $T$, namun sejumlah penelitian menunjukkan peran limfosit B dalam terjadinya sindrom nefrotik. Keberhasilan rituximab dalam tata laksana sindrom nefrotik idiopatik merupakan salah satu bukti terdapatnya peran limfosit B dalam patogenesis sindrom nefrotik. ${ }^{9,10}$

Limfosit B merupakan komponen penting dalam patogenesis penyakit autoimun, dan meningkat pada penyakit autoimun, sehingga eliminasi sel B dapat merupakan tujuan pengobatan. ${ }^{5,7}$ Limfosit B tidak hanya memproduksi antibodi dan berperan pada reaksi alergi, tetapi sel B juga berperan sebagai antigen-presenting cell (APC) yang mempresentasikan antigen terhadap limfosit $\mathrm{T}$, merekrut limfosit $\mathrm{T}$ autoreaktif, mensekresi sinyal ko-stimulasi yang diperlukan untuk aktivasi sel T CD4, dan sekresi sitokin inflamatori. Penelitian menunjukkan bahwa sel $\mathrm{B}$ turut berperan dalam patogenesis sindrom nefrotik, selain sel $T$ dan berhubungan dengan aktivitas sindrom nefrotik. ${ }^{11}$ Selain limfosit B, sel makrofag/ monosit diduga berperan penting dalam patogenesis sindrom nefrotik idiopatik. Antibodi anti-interleukin-8 dapat mencegah terjadinya sindrom nefrotik pada tikus coba yang diinfus dengan supernatan sel mononuklear darah perifer. ${ }^{10}$

Sebagian besar sindrom nefrotik idiopatik memberikan respon yang baik dengan steroid. Namun demikian, sindrom nefrotik dapat mengalami perjalanan penyakit yang lebih kompleks yang tidak responsif dengan steroid dan secara klinis disebut sindrom nefrotik refrakter, seperti sindrom nefrotik relaps frekuen atau dependen steroid dan sindrom nefrotik resisten steroid. Sindrom nefrotik relaps frekuen adalah sindrom nefrotik yang mengalami relaps dua kali atau lebih dalam enam bulan sejak respon awal atau empat kali atau lebih dalam satu tahun. Sedangkan sindrom nefrotik dependen steroid adalah sindrom nefrotik yang relaps ketika dosis prednison diturunkan atau dalam 14 hari setelah prednison dihentikan, terjadi dua kali berturut-turut. Sindrom nefrotik resisten steroid adalah sindrom nefrotik yang tidak remisi setelah diberi prednison dosis penuh selama empat minggu. ${ }^{12}$

Sindrom nefrotik refrakter dapat berupa sindrom nefrotik yang disebabkan glomerulonefritis kelainan minimal, membranosa idiopatik, dan glomerulosklerosis fokal segmental. Pada sindrom nefrotik kelainan minimal terdapat peningkatan produksi interleukin-
13 (IL-13) dan peningkatan ekspresi IL-13 mRNA. IL-13 merupakan sitokin yang berkaitan dengan sel $\mathrm{T}$ helper (Th2), yang merupakan bagian dari respon imun yang melibatkan sel $\mathrm{B}$. Kemper $\mathrm{dkk}^{9}$ menemukan peningkatan kadar sCD23 (petanda untuk aktivasi sel B) dan sCD25 (petanda untuk aktivasi sel T) selama keadaan relaps pada sindrom nefrotik dependen steroid. Cho $\mathrm{dkk}^{13}$ juga mengobservasi ekspresi CD23 dalam sel-B fresh yang jumlahnya lebih tinggi secara bermakna pada pasien sindrom nefrotik kelainan minimal yang aktif. Glomerulonefritis kelainan minimal merupakan penyakit sistemik yang berkaitan dengan imunitas sel $\mathrm{T}$ yang bekerja dengan menghambat sel $\mathrm{B}$ yang berfungsi dalam pengaturan sel T. ${ }^{14}$

Glomerulonefritis membranosa idiopatik merupakan penyakit imun yang terjadi karena deposit IgG dan komplemen pada lapisan subepitelial membran basalis glomerulus. Deposit imun berasal dari aktivasi sel B. Kompleks imun subepitelial dan aktivasi komplemen menyebabkan insufisiensi fungsional glomerulus yang menyebabkan gangguan sawar filtrasi glomerulus dan proteinuria. Imunisasi terhadap berbagai antigen podosit non spesifik seperti megalin, endopeptidase netral, dan aminopeptidase dapat menyebabkan glomerulonefritis membranosa idiopatik. Adanya infiltrasi sel B berupa infiltrasi interstitial fokal atau difus menyebabkan dugaan peranan sel B dalam patogenesis glomerulonefritis membranosa idiopatik, kemungkinan melalui sel antigen presenting cell. Penelitian lain juga menunjukkan adanya jalur tergantung sel-B yang menimbulkan pembentukan antibodi patogenik dan manifestasi klinis glomerulonefritis membranosa idiopatik. Selain itu, IgG4 (Th-2 type subclass) predominan pada glomerulonefritis membranosa idiopatik. ${ }^{14}$ Pada tahap awal neropati membranosa idiopatik, obat yang menghambat atau mencegah produksi imunoglobulin nefritogenik oleh sel B akan menghambat rangkaian kejadian progresivitas disfungsi ginjal. Telah terbukti bahwa jalur Th2 untuk mendapatkan respon terhadap antibodi, diaktivasi dan diinhibisi oleh sel B. ${ }^{15}$

Dalam patogenesis glomerulosklerosis fokal segmental, faktor permeabilitas sirkulasi memegang peran kunci yang telah dibuktikan oleh berbagai penelitian, terjadinya proteinuria pada tikus coba yang diberi plasma pasien glomerulosklerosis fokal yang mengindikasikan bahwa sitokin sel $\mathrm{T}$ dapat menimbulkan sindrom nefrotik, atau 
plasmaferesis yang memperbaiki proteinuria. Didapatkan proteinuria segera berkurang setelah sel $\mathrm{B}$ hilang, yang menunjukkan peran penting sel B dalam patogenesis proteinuria. ${ }^{14}$

\section{Mekanisme kerja rituximab}

Mekanisme rituximab untuk menginduksi remisi pada sindrom nefrotik belum jelas, namun demikian telah dikemukakan beberapa teori. ${ }^{2,3}$ Rituximab berperan langsung dalam patogenesis sindrom nefrotik, dengan menyebabkan deplesi sel $\mathrm{B}$ secara langsung atau menghambat interaksi antara sel $\mathrm{B}$ dan sel $\mathrm{T}$. Beberapa mekanisme farmakologi rituximab antara lain, sitotoksisitas yang dimediasi antibodi tergantung sel, sitotoksistas tergantung komplemen, induksi apoptosis, inhibisi proliferasi sel, rekruitmen sel efektor, dan aktivasi sitokin. ${ }^{4}$ Secara invitro maupun invivo, diduga aksi predominan antibodi adalah melalui cellmediated lysis. ${ }^{2,3}$

Dalam keadaan normal, limfosit B berperan dalam perkembangan arsitektur limfoid untuk mengatur fungsi subset sel-T dan sel dendritik melalui produksi sitokin serta aktivasi sel T. Dengan demikian, deplesi sel $\mathrm{B}$ dapat menghambat akivasi sel $\mathrm{T}$ yang diinduksi oleh sel B atau derivat sel B. ${ }^{3}$

Rituximab adalah antibodi monoklonal antiCD20 yang terikat secara spesifik terhadap antigen CD20 yang terletak pada limfosit pre-B dan limfosit-B matur. Rituximab terikat pada CD20 dengan afinitas yang tinggi; CD20 adalah glikoprotein permukaan semua sel limfosit B yang terdapat pada stadium sel pre-B dan menghilang selama diferensiasi sel plasma. Selain hal tersebut, CD20 merupakan petanda sel B yang diekspresikan pada permukaan pre- $\mathrm{B}$, dan sel limfosit B dalam keadaan istirahat atau teraktivasi. Fungsi sesungguhnya CD20 belum diketahui, tetapi sangat penting dalam aktivasi limfosit-B., ${ }^{4,5,10}$ Rituximab menyebabkan deplesi limfosit B (sel B darah perifer dan sel B kelenjar getah bening) dengan mematikan sel CD20+ melalui lisis yang dimediasi oleh komplemen (complement-mediated lysis) dan mencetuskan aktivitas selular berupa sitotoksik yang dimediasi sel tergantung antibodi (antibody dependent cell-mediated cytotoxicity). Deplesi sel-B oleh rituximab dapat menghambat aktivasi sel $\mathrm{T}$ yang diinduksi oleh sel B atau faktor yang berasal dari sel B. Meski rituximab mendeplesi sel CD210+, tetapi tidak mempunyai dampak pada sel plasma., ${ }^{5,10}$ Setelah pemberian rituximab, produksi sitokin sel $\mathrm{T}$ termasuk IL-13 dapat berkurang. ${ }^{3}$

Ekspresi molekul ko-stimulatori CD-40 terikat terhadap limfosit T CD4+ dan secara bermakna menurun sebagaimana ekspresi banyak petanda aktivasi limfosit T. Perubahan tersebut berkorelasi dengan efikasi klinik rituximab. ${ }^{5}$ Telah dibuktikan bahwa rituximab menurunkan CD40L dan CD80expressing cells di antara sel B dan CD69 pada sel CD4+. Sehingga menggambarkan bahwa rituximab dapat menghambat interaksi antara sel B dan sel T-teraktivasi. Namun demikian, peran CD40L pada pasien sindrom nefrotik dependen steroid aktif belum jelas. ${ }^{1,2}$ Dampak rituximab disebabkan inhibisi pembentukan deposit imun subepitel glomerulus karena reaksi yang dimediasi oleh sel B, serta inhibisi selektif clones autoakif yang memproduksi imunoglobulin nefritogenik. ${ }^{4}$

Mekanisme rituximab menginduksi remisi pada glomerulosklerosis fokal segmental belum jelas, tetapi dalam patogenesis glomerulosklerosis fokal terdapat faktor sirkulasi. Telah dilaporkan terdapat faktor permeabilitas berupa protein berat molekul rendah yang mempunyai muatan anionik, terikat pada protein $A$, dan mungkin mempunyai struktur yang sama dengan imunoglobulin-fragment-like. Meskipun sumber immunoglobulin-fragment-like sebagai faktor permeabilitas belum diketahui, namun kemungkinan sel B memproduksi faktor permeabilitas tersebut, sehingga penurunan sel B karena pemberian rituximab dapat menginduksi remisi pada sindrom nefrotik resisten steroid karena glomerulosklerosis fokal. ${ }^{3}$ Mekanisme rituximab untuk mencegah relaps pada sindrom nefrotik belum jelas. ${ }^{1}$

\section{Dosis dan cara pemberian rituximab}

Rituximab diberikan secara intravena setelah terjadi remisi dengan pemberian steroid, namun dapat juga diberikan meskipun belum terjadi remisi. ${ }^{1}$ Regimen yang sering digunakan dengan dosis $375 \mathrm{mg} / \mathrm{m}^{2} \mathrm{LPB}$ (maksimum $500 \mathrm{mg}$ ) secara intravena, diberikan 4 dosis dengan interval satu minggu. ${ }^{2,4,10,12,16.17}$ Dosis regimen lain adalah dengan dosis $750 \mathrm{mg} / \mathrm{m}^{2} \mathrm{LPB}$, diberikan dua dosis selang waktu 14 hari. ${ }^{12}$ Beberapa peneliti memberikan dengan dosis tunggal. Kamei $\mathrm{dkk}^{1}$ memberikan rituximab $375 \mathrm{mg} / \mathrm{m}^{2} \mathrm{LPB}$ dosis tunggal dengan hasil efektif untuk terapi sindrom 
nefrotik dependen steroid yang refrakter tetapi efikasi untuk mencegah relaps sangat singkat pada sebagian besar pasien. Nwobi $\mathrm{dkk}^{7}$ memberikan rituximab dengan dosis $375 \mathrm{mg} / \mathrm{m}^{2} \mathrm{LPB}$ perinfus selama 6-8 jam. Pemberian rituximab dosis tunggal pernah juga dilaporkan dengan hasil yang baik. ${ }^{2,3}$

Sesungguhnya, berdasarkan literatur belum ada dosis rituximab yang optimal dalam tata laksana sindrom nefrotik refrakter, namun pada umumnya diberikan $375 \mathrm{mg} / \mathrm{m}^{2}$ LPB sekali seminggu. Pemberian dosis $375 \mathrm{mg} / \mathrm{m}^{2} \mathrm{LPB}$ sekali seminggu selama 4 minggu sebenarnya mengacu pada dosis yang direkomendasikan pada limfoma sel-B. ${ }^{1}$ Untuk memperkecil reaksi akibat infus rituximab, didahului dengan pemberian premedikasi 30 menit sebelum rituximab, berupa antipiretik, kortikosteroid, dan penghambat histamin $\mathrm{H} 1$ dan $\mathrm{H} 2 .{ }^{4}$ Nwobi $\mathrm{dkk}^{7}$ memberikan difenhidramin dan parasetamol. Kamei $\mathrm{dkk}^{1}$ memberikan asetaminofen dan siproheptadin, selanjutnya pasien diobservasi selama paling tidak 24 jam setelah infus rituximab.

\section{Hasil pengobatan}

Pada umumnya, pengobatan sindrom nefrotik dengan rituximab memberikan hasil yang menjanjikan, bahkan beberapa penulis yang menyebutkan hasil pengobatan yang dramatis. Benz $\mathrm{dkk}^{4}$ melaporkan seorang anak usia dua tahun dengan sindrom nefrotik relaps sering dengan gambaran patologi anatomi kelainan minimal, yang sudah diterapi dengan prednison dan siklosporin. Pada usia 12 tahun, gambaran biopsi ginjal menunjukkan glomerulosklerosis fokal segmental dan diterapi dengan siklofosfamid dan karena hasil pengobatan tidak memuaskan, diterapi dengan takrolimus. Setelah 9 bulan pengobatan, pasien menderita diabetes melitus. Pada usia 15 tahun, pasien didiagnosis dengan sindrom nefrotik dependen steroid dan purpura trombositopeni imunologik dengan trombosit 6.000/uL, dan diterapi dengan rituximab $375 \mathrm{mg} / \mathrm{m}^{2}$ LPB sekali seminggu selama 4 minggu. Sebelumnya diberikan premedikasi dengan antipiretik, kortikosteroid, dan penghambat histamin $\mathrm{H} 1$ dan $\mathrm{H} 2$. Empat minggu setelah pengobatan, trombosit normal menjadi $217.000 / \mathrm{uL}$ dan pasien mengalami remisi dan tidak relaps lagi.

Hofstra $\mathrm{dkk}^{16}$ melaporkan seorang anak usia dua tahun dengan sindrom nefrotik idiopatik, yang kemudian didiagnosis sebagai sindrom nefrotik relaps sering. Pada usia empat tahun dilakukan biopsi ginjal dengan hasil kelainan minimal dan diterapi dengan siklofosfamid yang mengalami remisi 18 bulan. Setelah itu pasien sering mengalami relaps dan sudah diterapi dengan berbagai imunosupresan termasuk siklosporin. Pasien didiagnosis sebagai sindrom nefrotik dependen steroid. Pada usia 18 tahun, perjalanan penyakit sulit dikontrol meskipun sudah diterapi dengan kombinasi mikofenolat mofetil (MMF), prednison selang sehari, dan takrolimus. Akhirnya pasien diterapi dengan rituximab $1000 \mathrm{mg}$ intravena dua dosis dengan interval dua minggu, dan MMF dihentikan. Hasilnya, setelah 2 minggu, terjadi penurunan proteinuria dan peningkatan albumin serum. Takrolimus dan prednison di tappering-off. Empat bulan setelah pemberian rituximab, pasien mengalami keadaan remisi total, albumin dan kreatinin serum normal, dan pasien hanya mendapat prednison $7,5 \mathrm{mg} /$ hari selang sehari tanpa ada relaps. Disimpulkan bahwa rituximab memberikan hasil yang dramatis dalam tata laksana sindrom nefrotik dependen steroid, namun diperlukan uji klinik untuk melihat efikasi dan keamanan obat ini.

Kaito $\mathrm{dkk}^{11}$ melaporkan keberhasilan pengobatan sindrom nefrotik resisten steroid yang merupakan gomerulosklerosis fokal segmental dengan rituximab yang dikombinasi dengan steroid dan siklosporin. Dua bulan setelah pemberian rituximab pertama, CD-20 mengalami perbaikan dan terdapat penurunan limfosit B subset CD-20 pada darah perifer dari 17,3\% menjadi $0,05 \%$. Meskipun rituximab memperbaiki proteinuria, namun deplesi sel B tidak menginduksi remisi total. Relaps setelah pemberian rituximab sering dikaitkan dengan peningkatan jumlah sel CD20. Rituximab dapat mengurangi aktivitas penyakit dan memperbaiki sensitivitas terhadap obat imunsupresan.

Kamei $\mathrm{dkk}^{1}$ melaporkan penelitian prospektif multisenter untuk mengevaluasi efikasi rituximab pada 12 pasien sindrom nefrotik dependen steroid dengan pemberian dosis tunggal $375 / \mathrm{m}^{2} \mathrm{LPB}$, dan semua pasien sudah diterapi dengan siklosporin. Gambaran patologi anatomi berupa kelainan minimal pada 11 pasien dan satu pasien dengan glomerulosklerosis fokal segmental, dengan rerata durasi terapi steroid sebelum pemberian rituximab $(6,1 \pm 3,3)$ tahun. Pada semua pasien dapat dilakukan penghentian prednisolon pada median 74 hari setelah pemberian rituximab, dan dosis prednisolon secara bermakna menurun antara bulan kedua dan kelima setelah infus 